\title{
El estrés y la toma de decisiones en los jefes y los líderes policiales
}

\section{Contexto y relevancia}

El bienestar policial es un área donde se generan programas y proyectos dirigidos al bienestar del personal, algunos de tipo paliativo y otros de tipo preventivo. Es un aspecto comúnmente relacionado con la eficacia policial, respecto de la delicada tarea que desempeña la institución en la proporción de seguridad pública. Se asume que el talento humano es el pilar de las organizaciones, y por ello, es importante tener personal motivado, identificado y dispuesto a realizar sus funciones de la mejor manera; sin embargo, las instituciones policiales suelen ser organizaciones sui generis, generalmente cerradas al resto de la sociedad, con códigos internos informales fuertes, sistemas de valores y de movilidad interna singulares. Todo ello obliga a los investigadores a observar con detalle dichas características organizacionales.

De hecho, en países como El Salvador, la opinión sobre el bienestar policial suele estar referida a este factor como "variable independiente" de la eficacia policial; son pocas las perspectivas que estudian el problema por sus efectos en la persona, en el policía. Como dato ilustrativo, véanse las siguientes cifras sobre criminalidad en este país: en el año 2015 se presentó un índice de 103 homicidios por cada cien habitantes, mientras que en el año 2016 este mismo índice se situó en un valor de 86; por su parte, en el año 2015 se registraron 63 homicidios de policías, la mayoría relacionados con la escalada violenta entre pandillas y Estado, luego del fin de la tregua entre pandillas (pacto de no agresión entre pandillas que fue facilitado por el gobierno de El Salvador) (López, 2017). Este ambiente de violencia implica mayores niveles de exigencia, carga laboral y emocional; los cuales pueden devenir en estrés ocupacional e insatisfacción laboral. 


\section{Contenidos}

El capítulo al que se refiere esta sinopsis posee una extensión corta pero contiene elementos esenciales para adentrarse en un tema de gran interés para el bienestar policial. El autor, David Mutton, es un académico con amplia experiencia como psicólogo en instituciones del sistema penal y como profesor universitario en Australia, nación donde están contextualizados los contenidos del capítulo; no obstante lo anterior, el texto posee un alto potencial para realizar extrapolaciones a otros cuerpos policiales, habida cuenta de las especificidades inherentes a cada contexto.

El capítulo aborda el asunto del estrés ocupacional en instituciones policiales, poniendo énfasis en el estrés que presentan los jefes policiales de distinto nivel jerárquico. Para ello, el autor se cuestiona dos asuntos principales:

1. Por qué estudiar el estrés en policías.

2. Qué fuentes de estrés presentan los policías.

Respecto a la primera pregunta, hay una noción general sobre la profesión de policía, muy asentada en el imaginario popular: los policías desarrollan labores inherentemente estresantes y por ello es lógico pensar que presentan niveles de estrés mayores. El autor problematiza lo anterior afirmando que de manera comparativa, no se puede asegurar que este grupo profesional presente los mayores niveles de estrés laboral, de hecho, todas las profesiones se enfrentan a este fenómeno. Sin embargo, el interés por estudiar este asunto con este grupo en especial, se debe más bien al tipo de labores que desempeñan los policías: realizan funciones especialmente importantes para la sociedad, la cual les exige eficacia; y por otra parte, hacen uso de la fuerza, por lo tanto, pueden presentar riesgos tanto para compañeros, ciudadanos y presuntos infractores de la ley. Esto último es lo que motiva el estudio del estrés ocupacional en este grupo profesional.

En cuanto al segundo punto, es curioso encontrar hallazgos de investigaciones donde se ha identificado claramente que las fuentes del estrés en policías no provienen de los riesgos inherentes de su labor, los cuales son generalmente identificados como aspectos usuales del quehacer policial por parte del sentido común: hechos de violencia. Estos últimos se denominan "incidentes críticos" en la literatura especializada. 


\title{
LIBROS
}

Para efectos ilustrativos, se retoma una ficha cualitativa presentada en el capítulo, donde se expone de manera resumida el punto recién planteado:

\begin{abstract}
"Los oficiales de policía que participan de cualquier tipo de sesiones de manejo del estrés, rara vez citan el peligro ni otros incidentes críticos angustiantes como las fuentes principales de estrés. Tienen una mayor tendencia a hablar de la mala administración, la falta de recursos, las excesivas caga de trabajo, la decepción que sufren por el sistema legal y otros problemas de la organización como factores de desgaste en el lugar de trabajo. A veces había que recordarles que el peligro y los incidentes críticos podían incluso considerarse posibles causas de estrés. Pero para algunos el peligro y el nerviosismo había sido lo que los había motivado a unirse a la policía en un principio" (Mutton, 2010, p. 313).
\end{abstract}

Derivado de lo anterior, cae por su propio peso la necesidad de estudiar el estrés en las jefaturas policiales, pues si los factores organizacionales son los mayor ponderados en cuanto a causas, entonces es importante analizar el estrés en los tomadores de decisiones en calidad de jefaturas organizacionales y generadores de clima laboral.

Una particularidad de los cuerpos policiales planteada en el texto, es la carrera policial, ya que para ocupar puestos de jefatura, alguien tendría que haber recorrido distintos niveles internos y logrado ascensos de rango. De acuerdo al autor, los mecanismos de ascenso en las policías no suelen premiar la innovación y el desempeño, sino más bien la ausencia de errores. Las jefaturas, en tanto tomadores de decisión, se someten a un tipo de estrés diferente al resto de policías.

Algunas de las particularidades (y causas) del estrés ocupacional en jefaturas policiales son las siguientes:

1. Presentan preocupación por problemas de tipo organizacionales, pero no de carácter operativo, sino referidos a aspectos políticoinstitucionales y acceso a recursos.

2. Han desarrollado estrés y traumas en su carrera de ascenso, esto por haber pasado por distintas áreas.

3. Han desarrollado lealtades entre oficiales de policía en su ascenso en la carrera y ello frecuentemente genera situaciones relacionadas al estrés. 
Las jefaturas policiales suelen presentar menos niveles de estrés ocupacional que los policías operativos; en general, son personas de mayor edad y que han logrado ascender en su carrera, lo cual puede hacer más aceptables ciertas situaciones organizativas. Esto a su vez plantea el debate, también presente en El Salvador, de la brecha entre preocupaciones operativas y preocupaciones político-administrativas, lo cual podría traducirse en una posible desconexión entre las necesidades de desarrollo del sector operativo y de los tomadores de decisión, quienes no están expuestos a las tareas de seguridad pública en la calle.

Lo anterior se relaciona con un fenómeno presente en todos los niveles policiales, algo que emerge de las situaciones críticas y la imposibilidad de manejarlas de manera asertiva. El autor lo ilustra mediante el siguiente ejemplo:

"Una cónyuge de un oficial superior afirmó que con el paso de los años su marido se había vuelto más duro, insensible e intolerante con los pequeños infortunios que sufrían los miembros de su familia, lo cual hizo que la relación con sus hijos se volviera distante y poco comprensiva. Asimismo, con frecuencia su esposa sentía que durante las discusiones la interrogaba como a una delincuente, o que sentía tener que defenderse como una testigo en un banquillo de testigos. El resultado era que ella y sus hijos se sentían desconectados de su esposo. El oficial superior, que sin duda alguna había enfrentado sufrimiento y traumas reales de primera mano en muchos incidentes críticos, me expresó su filosofía de vida: Estás con vida, así que deja de quejarte. Sentimientos de desconexión similares explican, en parte, muchas de las rupturas de relaciones que sufren los oficiales de policía" (Mutton, 2010, p.320).

Tal desconexión emocional podría tener efectos adversos en la administración del talento humano, en el trato a ciudadanos y en las relaciones sociales del policía. Aunado a ello, el jefe policial debe enfrentar presiones de tipo político administrativo y ser capaz de superar la brecha de prioridades con los policías operativos.

El autor finaliza proponiendo, que si bien es importante estudiar las fuentes del estrés ocupacional policial, también deben estudiarse las maneras de enfrentar y resistir la adversidad; pues este asunto siempre estará presente en las instituciones policiales y muchas veces no será posible evitarlo. 


\section{LIBROS}

\section{Bibliografía}

Mutton, D. (2010). El estrés y la toma de decisiones en los jefes y los líderes policiales. páginas 311-325. En M. Mitchell y J. Casey (Eds.). Conducción y administración policiales. Buenos Aires, Argentina: Editorial Prometeo. 468 páginas.

López R., A. (2017). Patrullaje policial a pie en zonas con alta presencia de pandillas. Valoraciones para la educación policial. Revista Policía y Seguridad Pública, 7(1), 271-320. doi:http://dx.doi.org/10.5377/rpsp. v7i1.4313

Sinopsis elaborada por Augusto Rigoberto López Ramírez Centro de Investigación Científica Academia Nacional de Seguridad Pública 